\title{
AN INVESTIGATION ABOUT HEAVY METAL POLLUTION OF DUDEN AND GOKSU STREAMS (ANTALYA, TURKEY)
}

\author{
LEVENTELI, $\mathrm{Y}^{1 *}-\mathrm{YALCIN}^{*} \mathrm{~F}^{2}-\mathrm{KILIC}, \mathrm{M}^{3}$ \\ ${ }^{1}$ Department of Geological Engineering, Akdeniz University, 07058 Antalya, Turkey \\ ${ }^{2}$ Department of Mathematics, Akdeniz University, 07058 Antalya, Turkey \\ ${ }^{3}$ Food Safety and Agricultural Resc. Cent., Akdeniz University, 07059 Antalya, Turkey \\ *Corresponding author \\ e-mail: leventeli@akdeniz.edu.tr \\ (Received $5^{\text {th }}$ Oct 2018; accepted $2^{\text {nd }}$ Jan 2019)
}

\begin{abstract}
The cities are also expanding with growth in construction rapidly, depending on the population growth. This development causes a lot of environmental problems. Pollution in water is one of the main problems and the aim of this paper is to evaluate water pollution in the study area. There are some statistical methods developed for the measurement and evaluation of water pollution; heavy metal pollution index (HPI) is one of them. Antalya is, one of the big cities in Turkey, also growing fast; population and settlement in this city are increasing quickly. That is why two streams, Duden and Goksu, are selected to measure the heavy metal pollution. The 24 water samples from Duden Stream and 18 water samples from Goksu Stream were taken systematically in June 2018 and were analyzed by using HPI. The heavy metals, from the highest value to the lowest one, were $\mathrm{Sr}>\mathrm{Fe}>\mathrm{Al}>\mathrm{Mn}>\mathrm{As}>\mathrm{Ni}>\mathrm{Cu}$ $>\mathrm{Pb}>\mathrm{Cr}>\mathrm{Se}$ in Duden Stream; and $\mathrm{Sr}>\mathrm{Fe}>\mathrm{Al}>\mathrm{Ni}>\mathrm{As}>\mathrm{Cu}>\mathrm{Mn}>\mathrm{Pb}>\mathrm{Cr}>\mathrm{Se}$ in Goksu Stream. The $\mathrm{Sr}$ and $\mathrm{Al}$ values have exceeded the standard permissible values in both of the streams. The heavy metal pollution index (HPI) was used to evaluate the potential risk. Regarding quality the water samples have been classified as "good" and "poor", generally. On the other hand, some water samples had heavy metal pollution above standards. Especially, the water of D15 - D19 - D20 and G13 samples were determined as "very poor" according to the standards. As a conclusion, the anthropogenic factors and urbanization may be the cause of the pollution. Living creatures that use water may have health problems and ecological equilibrium may be hampered in these stations. Groundwater may be contaminated in these areas. So, the urbanization needs to be done more carefully.
\end{abstract}

Keywords: heavy metal pollution index (HPI), urbanization, statistics, surface water, environment

\section{Introduction}

The urbanization may cause pollution. This question becomes much more important, especially in industrial areas. The quality of environment has been influenced by the diffusion of pollutants in air, water and soil in large areas. The accumulation of pollutants has disturbed the ecological equilibrium, in time (Stoica and Baiulescu, 2008). The reason of the heavy metal pollution in water could be natural or anthropogenic (Zarazua et al., 2006; Mehrabi et al., 2015; Sobhanardakani, 2016). Bhuiyan et al. (2015) reported "The heavy metal evaluation index (HEI) showed strong correlations and provided better assessment of pollution levels with HPI."

Duden Stream flows in the Lara Region of Antalya Bay and it is an example for pollution (Erdem and Topkaya, 2004). According to Yardimci et al. (2005), the other example is Goksu Stream which is the main source of Bogacay River. It feeds Bogacay River. So, Goksu Stream affects the water quality of the Bogacay River and the water quality changes temporally; the critical level of water quality was determined in summer because of the recreational activities. Cengiz et al. (2017) also evaluated the 
risk potential of metallic pollution in Bogacay River. According to this study, the samples from upstream showed lower risk potentials than those from downstream. Yalcin et al. (2016) also has investigated the contamination of the sediments by heavy metals along the banks of the Bogacay River. Demarco et al. (2018) and Uncumusaoglu et al. (2016) emphasized the importance of heavy metal pollution in streams in terms of environmental contamination and anthropogenic pollution. Besides, the heavy metal pollution in surface sediments has been also studied in the most recent papers (Ye et al., 2019; Sodrzeieski et al., 2018; Omwene et al., 2018).

Antalya, which is at the forefront of Turkey's major tourism centers and called the "Turkish Riviera", is quite rich in terms of water resources. The water is provided from underground waters. However, Antalya is located on tufa which has a karstic structure. Because of that, water moves frequently from the underground to the surface or from the surface to the underground. On the other hand, the population growth is remarkable in the $5^{\text {th }}$ largest city of the country. Parallel to this, settlement areas are also expanding. The western part of the city is the best example of fast construction. The construction and also population growth continues on both sides of the city. Therefore, the protection of the existing water has become more important and the quality and/or quantity of water should be investigated to prevent pollution.

Although some studies have been made on this subject, no data has been obtained on heavy metal pollution in Duden and Goksu streams after the built-up and population growth. The surface water, which is coming out from the Kepez Hydroelectric Power Plant, reaches via two channels to the Mediterranean; one of them is Duden Falls in Lara tourist area, the other one is Bogacay River in Konyaalti district. However, the second one passes Goksu Stream before Bogacay River (Leventeli et al., 2017). In this study, heavy metal pollution in the surface water was investigated and analyzed statistical between Kepez Hydroelectric Power Plant and Duden Falls in Lara tourist area, called Duden Stream and also between Kepez Hydroelectric Power Plant and Bogacay River with Goksu Stream in Konyaalti district. The location map of the study area, including the sampling stations, is given in Figure 1.

\section{Experimental}

\section{Study area}

The study area is located in the city center of Antalya district which is one of the big cities in Turkey. The water which is coming out from the Kepez Hydroelectric Power Plant reaches via two channels to Mediterranean; one of them is Duden Falls in Lara tourist area, the other one is Goksu Stream with a part of the Bogacay River in Konyaalti district. There are agricultural, industrial and residential areas in the region.

\section{Field sampling}

The samples were collected from 42 locations in June 2018 based on morphological and land use properties of the study area. $1 \mathrm{~L}$ polythene containers are used for the collection according to standard procedures. Because of the dry season, surface water samples have been taken at this time. D in numbers of samples means "taken from Duden Stream", G means "taken from Goksu Stream”. Goksu Stream has a $10.5 \mathrm{~km}$ length and Duden Stream has $28.5 \mathrm{~km}$ length. So, 24 samples were taken from Duden Stream and 18 samples from Goksu Stream. There are natural barriers like barbed wire, 
morass, prohibited agricultural areas and so on. The long symbols show the stations of Duden Stream and the round symbols show the stations of Goksu Stream (see Fig. 1).

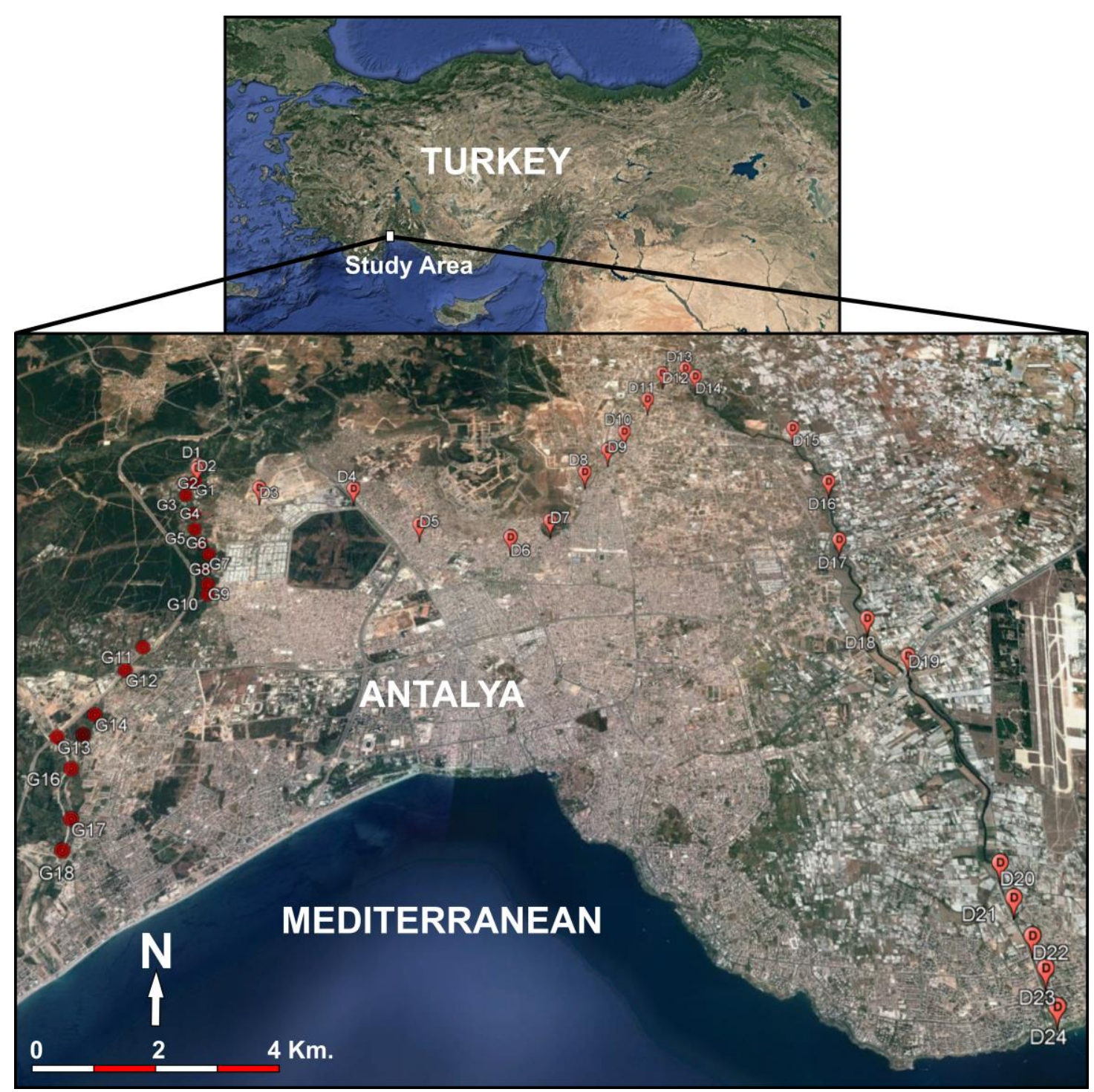

Figure 1. The location map of the study area shows the sampling stations

\section{Laboratory methods}

\section{Preparation of samples}

The experimental studies have been done in the Research Center Laboratory of Akdeniz University. Water samples acidified by adding $5 \mathrm{ml}$ of nitric acid to $1 \mathrm{~L}$ polyethylene bottle ISOLAB mark tubes. The biological activities of microorganisms and bacteria that may be in the environment have been terminated in order to prevent the transformation of metals into other forms. The samples were kept in the refrigerator until analysis, and then they were filtered through the filter paper. $2 \mathrm{ml}$ of nitric acid was added after pre-treatment to acidify the samples according to EPA 3005A (1992) method (Rohrbough et al., 1986; ASTM 1985). Table 1 shows the device parameters of 
Inductively Coupled Plasma - Mass Spectrometer (ICP-MS). A certified standard (SPSSW2 surface water) was used to verify method trueness.

Table 1. Device parameters of ICP-MS (Perkin Elmer Elan DRC-e)

\begin{tabular}{|c|c|}
\hline Spectrometer & Elan DRC-e (Perkin Elmer SCIEX, Norwalk, CT, USA) \\
\hline Sample Introduction & Scott Spray Chamber \\
\hline RF Power & 1000 \\
\hline Skimmer Cone & Nickel \\
\hline Sampler Cone & Nickel \\
\hline Gas flow rates $\left(\mathrm{L} \mathrm{min}{ }^{-1}\right)$ & Nebulizer gas flow:0.81 Auxillary gas flow:1.20 Plasma gas flow:19 \\
\hline Scanning mode & Peak hopping \\
\hline Reaction gas, $\mathrm{CH}_{4}\left(\mathrm{ml} \mathrm{min}^{-1}\right)$ & Cell gas A $0.2 ; \mathrm{RPq} 0.8$ BEC (ppb) 0.1463 (As 74.9216) \\
\hline Number of sweeps/reading & 20 \\
\hline Number of readings/replicate & 1 \\
\hline Number of replicates & 3 \\
\hline Auto sampler & CETAX ASX-520 \\
\hline Dwell time per AMU (ms) & 50 \\
\hline Sample flush & Time (50), speed (+/- rpm)-48 \\
\hline Read delay & Time (15), speed (+/- rpm)-20 \\
\hline
\end{tabular}

\section{Statistical methods and heavy metal pollution index (HPI)}

The results of the analyses have been given below with calculations and also with assessments have been made using the Descriptive Analysis, Multivariate Statistics Analysis (Correlations, Principal Component, Component Matrix, Hierarchical Analysis) and Heavy Metal Pollution Index (HPI). Multivariate Statistics Analysis has been made using SPSS-23 software. Besides that, EXCEL 2016 software has been used for HPI calculations, according to similar works.

\section{Results and discussions}

\section{Chemical data, statistical surveys}

The water samples were taken at the same time from the streams to investigate the existence of iron $(\mathrm{Fe})$, lead $(\mathrm{Pb})$, arsenic $(\mathrm{As})$, copper $(\mathrm{Cu})$, manganese $(\mathrm{Mn})$, nickel $(\mathrm{Ni})$, aluminum $(\mathrm{Al})$, cobalt $(\mathrm{Co})$, strontium $(\mathrm{Sr})$, chromium $(\mathrm{Cr})$, selenium $(\mathrm{Se})$, antimony $(\mathrm{Sb})$, mercury $(\mathrm{Hg})$ and cadmium $(\mathrm{Cd})$ elements. The amount of heavy metal elements obtained is given in Table 2 in ppb ( $\mu \mathrm{g} / \mathrm{L})$. However; antimony $(\mathrm{Sb})$, mercury $(\mathrm{Hg})$ and cadmium $(\mathrm{Cd})$ were not detected in any samples. Cobalt $(\mathrm{Co})$ values were below reporting limit. Chromium $(\mathrm{Cr})$ and selenium $(\mathrm{Se})$ values were below reporting limit generally, excepting some samples; Cr values are 1.7 in G1, 2.5 in G2, 1.2 in G3, 4.7 in G9, 4.3 in G10, 2.1 in D12 and 2.9 in D13; Se values are 0.4 in G7, 0.5 G9, 0.3 G10, 2.1 in D12 and 2.9 in D13.

Descriptive statistics of metal concentration are presented in Table 3. The heavy metals were arranged from the highest value to the smallest one as $\mathrm{Sr}>\mathrm{Fe}>\mathrm{Al}>\mathrm{Mn}>$ As $>\mathrm{Ni}>\mathrm{Cu}>\mathrm{Pb}>\mathrm{Cr}>\mathrm{Se}$ in Duden Stream. On the other hand, the order of the metal values from the highest value to the smallest one for Goksu Stream was as $\mathrm{Sr}>\mathrm{Fe}$ 
$>\mathrm{Al}>\mathrm{Ni}>\mathrm{As}>\mathrm{Cu}>\mathrm{Mn}>\mathrm{Pb}>\mathrm{Cr}>\mathrm{Se}$. Among these metals, the $\mathrm{Sr}$ and $\mathrm{Al}$ values have exceeded the standard permissible values in both of tributaries. The values of the other metals were far below standard values.

Table 2. The heavy metal values (ppb)

\begin{tabular}{|c|c|c|c|c|c|c|c|c|c|c|}
\hline NO & \multicolumn{2}{|c|}{ Coordinates } & $\mathbf{P b}$ & As & $\mathbf{C u}$ & $\mathrm{Fe}$ & Mn & Al & $\mathbf{N i}$ & $\mathbf{S r}$ \\
\hline D1 & 36S 0288246 & 4090629 & N.D. & 10 & 4.5 & 185 & 2.6 & 9 & 5.4 & 202 \\
\hline D2 & 36S 0288254 & 4090520 & N.D. & 9.9 & 3.4 & 183 & 1.3 & 5.9 & 4.3 & 317 \\
\hline D3 & 36S 0289513 & 4090059 & 2.2 & 9.6 & 4.9 & 212 & 1.8 & 7.5 & 23.5 & 421 \\
\hline D4 & 36S 0291260 & 4090070 & 8.1 & 8.9 & 30.7 & 254 & 7.9 & 13.3 & 9 & 298 \\
\hline D5 & 36S 0292577 & 4089230 & 5.5 & 9.1 & 4.7 & 189 & 1.3 & 6.8 & 24.6 & 309 \\
\hline D6 & 36S 0294242 & 4088960 & 1.5 & 9.2 & 6.3 & 198 & 1.6 & 16 & 18 & 305 \\
\hline D7 & $36 \mathrm{~S} 0294935$ & 4089369 & 2.9 & 9.6 & 4.9 & 248 & 3.2 & 9.3 & 5.2 & 336 \\
\hline D8 & 36S 0295524 & 4090582 & N.D. & 10.6 & 3.2 & 234 & 1.6 & 8.8 & 5 & 331 \\
\hline D9 & 36S 0295941 & 4091168 & 5.1 & 8.3 & 43.6 & 238 & 9.2 & 26.5 & 5.6 & 329 \\
\hline D10 & 36S 0296251 & 4091657 & 1.1 & 9.4 & 5.6 & 232 & 4.4 & 11.3 & 4.9 & 311 \\
\hline D11 & 36S 0296696 & 4092554 & 1.5 & 9.5 & 5.8 & 241 & 4.2 & 6 & 5.9 & 305 \\
\hline D12 & 36S 0296991 & 4093304 & 4.5 & 12.3 & 5.1 & 176 & 7.7 & 3.6 & 7.1 & 298 \\
\hline D13 & 36S 0297453 & 4093464 & N.D. & 12.1 & 30.6 & 156 & 9 & 3.7 & 5.1 & 285 \\
\hline D14 & 36S 0297650 & 4093229 & N.D. & 11.8 & 3.2 & 195 & 3.1 & 2.9 & 4 & 328 \\
\hline D15 & 36S 0299490 & 4091819 & 1.9 & 10.6 & 6.5 & 218 & 84.9 & 52.2 & 9.9 & 478 \\
\hline D16 & $36 \mathrm{~S} 0300061$ & 4090432 & N.D. & 11 & 5.1 & 185 & 30.8 & 9.9 & 4.5 & 425 \\
\hline D17 & $36 \mathrm{~S} 0300127$ & 4089027 & N.D. & 10.7 & 5 & 174 & 12.5 & 12.1 & 4.7 & 319 \\
\hline D18 & $36 \mathrm{~S} 0300445$ & 4087284 & N.D. & 11.6 & 3.5 & 151 & 15.5 & 6 & 4.1 & 357 \\
\hline D19 & 36S 0301044 & 4086519 & 2.3 & 7.8 & 3.8 & 221 & 85.4 & 81.3 & 18.8 & 365 \\
\hline D20 & 36S 0301940 & 4082808 & 4.3 & 9.7 & 4.8 & 213 & 82.5 & 78.4 & 19.4 & 325 \\
\hline D21 & $36 \mathrm{~S} 0302046$ & 4082257 & N.D. & 8.9 & 4.1 & 142 & 13.4 & 7.1 & 3.8 & 302 \\
\hline D22 & 36S 0302210 & 4081680 & N.D. & 10.2 & 3.1 & 168 & 12.9 & 16.7 & 3.2 & 298 \\
\hline D23 & $36 \mathrm{~S} 0302310$ & 4081209 & N.D. & 8.4 & 3.7 & 161 & 13.6 & 15.2 & 2.4 & 256 \\
\hline D24 & $36 \mathrm{~S} 0302363$ & 4080662 & 1.5 & 9.6 & 3.2 & 159 & 19 & 24.9 & 3.07 & 201 \\
\hline G1 & 36S 0288231 & 4090522 & N.D. & 9 & 3.8 & 238 & 1.2 & 3.5 & 11.2 & 299 \\
\hline G2 & 36S 0288179 & 4090460 & 1.9 & 8.3 & 3.7 & 227 & 1.4 & 5.8 & 4.5 & 301 \\
\hline G3 & 36S 0288131 & 4090151 & 0.7 & 9.4 & 4.1 & 239 & 1.4 & 3.5 & 12.8 & 322 \\
\hline G4 & 36S 0288388 & 4089712 & N.D. & 9.4 & 3.5 & 265 & 1.1 & 7.8 & 6.4 & 500 \\
\hline G5 & $36 \mathrm{~S} 0288477$ & 4089340 & 1 & 8.4 & 3.8 & 260 & 1 & 5.3 & 8 & 511 \\
\hline G6 & $36 \mathrm{~S} 0288663$ & 4089014 & 4.5 & 6.3 & 2.7 & 167 & N.D. & 1.2 & 8.1 & 455 \\
\hline G7 & $36 \mathrm{~S} 0288862$ & 4088752 & N.D. & 6.5 & 3.1 & 198 & 1 & N.D. & 5.2 & 361 \\
\hline G8 & $36 \mathrm{~S} 0288854$ & 4088410 & N.D. & 6.6 & 2.9 & 190 & N.D. & 2.6 & 6 & 358 \\
\hline G9 & 36S 0288992 & 4088071 & N.D. & 6.4 & 5.9 & 205 & 1 & 4.8 & 12.4 & 363 \\
\hline G10 & $36 \mathrm{~S} 0289033$ & 4087849 & N.D. & 6.3 & 4 & 185 & 1.1 & 6.2 & 7.3 & 353 \\
\hline G11 & 36S 0288180 & 4086714 & N.D. & 6.2 & 2.9 & 166 & N.D. & 2.6 & 4.9 & 357 \\
\hline G12 & $36 \mathrm{~S} 0288003$ & 4086239 & 3.7 & 6.4 & 3.6 & 157 & N.D. & 1.2 & 3.6 & 401 \\
\hline G13 & 36S 0287235 & 4084938 & 4.2 & 1.1 & 7.3 & 148 & 24 & 54 & 15 & 399 \\
\hline G14 & $36 \mathrm{~S} 0287727$ & 4085368 & N.D. & 6.7 & 3.5 & 182 & N.D. & N.D. & 2.9 & 420 \\
\hline G15 & 36S 0287639 & 4084992 & 2.4 & 7 & 17.4 & 174 & N.D. & 2.4 & 6.4 & 398 \\
\hline G16 & $36 \mathrm{~S} 0287624$ & 4084370 & N.D. & 6.9 & 5 & 164 & 6 & 14.4 & 8 & 366 \\
\hline G17 & 36S 0287869 & 4083497 & N.D. & 6.5 & 3.6 & 165 & 2.2 & 1.1 & 3.7 & 356 \\
\hline G18 & 36S 0287884 & 4082971 & 2.8 & 6.2 & 3.7 & 155 & 3.5 & 17.1 & 3.3 & 302 \\
\hline
\end{tabular}

N.D. Not detected 
Table 3. Descriptive statistics of water sample

\begin{tabular}{|c|c|c|c|c|c|c|c|c|c|}
\hline \multirow{2}{*}{$\begin{array}{c}\text { Parameter } \\
\mu \mathrm{g} / \mathrm{l}\end{array}$} & \multicolumn{4}{|c|}{$\begin{array}{c}\text { Duden Stream } \\
\mathbf{n}=\mathbf{2 4} \\
\end{array}$} & \multicolumn{4}{|c|}{$\begin{array}{c}\text { Goksu Stream } \\
\mathrm{n}=18 \\
\end{array}$} & \multirow{2}{*}{ 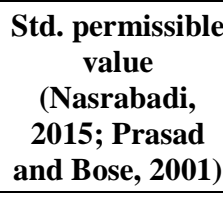 } \\
\hline & Min & Max & Mean & Std. dev. & Min & Max & Mean & Std. dev & \\
\hline $\mathbf{P b}$ & 0 & 8.1 & 1.766667 & 2.243961 & 0 & 4.5 & 1.177778 & 1.632593 & 50 \\
\hline As & 7.8 & 12.3 & 9.95 & 1.19855 & 1.1 & 9.4 & 6.866667 & 1.837518 & 50 \\
\hline $\mathbf{C u}$ & 3.1 & 43.6 & 8.304167 & 10.5732 & 2.7 & 17.4 & 4.694444 & 3.364079 & 1000 \\
\hline $\mathrm{Fe}$ & 142 & 254 & 197.2083 & 33.28661 & 148 & 265 & 193.6111 & 37.16599 & 1000 \\
\hline Mn & 1.3 & 85.4 & 17.89167 & 26.55961 & 0 & 24 & 2.494444 & 5.572355 & 300 \\
\hline Al & 2.9 & 81.3 & 18.1 & 21.66478 & 0 & 54 & 7.416667 & 12.50309 & 10 \\
\hline $\mathbf{N i}$ & 2.4 & 24.6 & 8.394583 & 6.853334 & 2.9 & 15 & 7.205556 & 3.560812 & 20 \\
\hline $\mathbf{S r}$ & 201 & 478 & 320.875 & 61.13301 & 299 & 511 & 379 & 61.98102 & 50 \\
\hline $\mathrm{Cr}$ & 0 & 2.9 & .2083333 & .7156126 & 0 & 4.7 & .8 & 1.527012 & 10 \\
\hline Se & 0 & 2.9 & .2083333 & .7156126 & 0 & .5 & .0666667 & .157181 & 10 \\
\hline
\end{tabular}

Significant correlation coefficients between 10 heavy metal behaviours in river water in 42 different stations are shown in Table 4. Positive correlation was determined between $\mathrm{Pb}$ and $\mathrm{Fe}, \mathrm{Cu}, \mathrm{Ni}$; between $\mathrm{As}$ and $\mathrm{Cr}$, Se; between $\mathrm{Mn}$ and $\mathrm{Al}$; between $\mathrm{Cr}$ and Se in Duden Stream. The highest correlation between these metals was determined between $\mathrm{Mn}$ and $\mathrm{Al}(0.923 *)$. The positive high correlation between $\mathrm{Mn}$ and $\mathrm{Al}$ showed that their potential sources may be the same in Duden Stream. There is a positive correlation between $\mathrm{As}$ and $\mathrm{Fe}$; between $\mathrm{Mn}$ and $\mathrm{Al}, \mathrm{Ni}$; between $\mathrm{Cr}$ and $\mathrm{Se}$, between $\mathrm{Al}$ and $\mathrm{Ni}$ in Goksu Stream. High positive correlation between $\mathrm{Mn}$ and $\mathrm{Al}$ is determined $(0.974 *)$. Besides, there is a high negative correlation relationship between As and Mn $\left(-0.748^{*}\right)$, As and $\mathrm{Al}\left(-0.715^{*}\right)$ in Goksu Stream. These correlations showed that $\mathrm{Mn}$ and $\mathrm{Al}$ may be from the same source. However, it can be said that As has a different source than Mn and Al in Goksu Stream.

According to the total variance of heavy metal content, the statistical evaluation of the chemical analysis results was high and calculated as $79.460 \%$ (Table 5). The explained total variance analysis is evaluated in two parts. One of them is "Initial Eigenvalues"; the other one is "Extraction Sums of Squared Loadings". The percentage of explanations of each factor is given in order; the cumulatively highest value gives percentage of explanations of the used data. The numerical data of this ratio, which reaches 100, explain its explanatory rate. Therefore, the cumulative value obtained as $79.460 \%$ was stated to be high in the factor analyzes of the article. A total of 4 factors were determined by factor analysis. The first factor was explained by $\mathrm{Al}, \mathrm{Mn}, \mathrm{Ni}, \mathrm{Pb}$. The second, third and fourth factors were respectively represented by $\mathrm{Cu}, \mathrm{As}$ and $\mathrm{Fe}$ (Table 6). Factors indicate possible sources. Metals within the same factor can be of similar origin in the first factor except other factors.

From the results of the hierarchical analysis, it is understood that three groups were formed among locations (Fig. 2). The first group of locations includes 28, 29 and 15 numbers. The second group of locations includes 1, 24 and 23 numbers. The third one includes total of the all numbers. These groups show similarities between the locations Excessive differences between locations show the excess of natural and anthropogenic factors acting on the streams. The analysis results are consistent with factor analysis and with the Principal Component Analysis. 
Table 4. Relationships between behaviour of heavy metals

\begin{tabular}{|c|c|c|c|c|c|c|c|c|c|c|c|}
\hline & & $\mathbf{P b}$ & As & $\mathbf{C u}$ & $\mathbf{F e}$ & Mn & Al & $\mathbf{N i}$ & $\mathbf{S r}$ & $\mathrm{Cr}$ & $\mathbf{S e}$ \\
\hline $\begin{array}{l}\text { Zn } \\
\text { 帘 } \\
\text { 它 }\end{array}$ & $\begin{array}{c}\mathrm{Pb} \\
\mathrm{As} \\
\mathrm{Cu} \\
\mathrm{Fe} \\
\mathrm{Mn} \\
\mathrm{Al} \\
\mathrm{Ni} \\
\mathrm{Sr} \\
\mathrm{Cr} \\
\mathrm{Se}\end{array}$ & $\begin{array}{c}1 \\
-.331 \\
.483^{*} \\
.533^{*} \\
.118 \\
.249 \\
.483^{*} \\
.041 \\
.016 \\
.016\end{array}$ & $\begin{array}{c}1 \\
-.126 \\
-.358 \\
-.147 \\
-.383 \\
-.327 \\
.129 \\
.566^{*} \\
.566^{*}\end{array}$ & $\begin{array}{c}1 \\
.282 \\
-.113 \\
-.024 \\
-.076 \\
-.047 \\
.332 \\
.332\end{array}$ & $\begin{array}{c}1 \\
.107 \\
.248 \\
.262 \\
.305 \\
-.299 \\
-.299\end{array}$ & $\begin{array}{c}1 \\
.923^{*} \\
.314 \\
.446 \\
-.107 \\
-.107\end{array}$ & $\begin{array}{c}1 \\
.425 \\
.259 \\
-.202 \\
-.202\end{array}$ & $\begin{array}{c}1 \\
.314 \\
-.108 \\
-.108\end{array}$ & $\begin{array}{c}1 \\
-.151 \\
-.151\end{array}$ & 1 & 1 \\
\hline 苟 & $\begin{array}{c}\mathbf{P b} \\
\mathrm{As} \\
\mathrm{Cu} \\
\mathrm{Fe} \\
\mathrm{Mn} \\
\mathrm{Al} \\
\mathrm{Ni} \\
\mathrm{Sr} \\
\mathrm{Cr} \\
\mathrm{Se}\end{array}$ & $\begin{array}{c}1 \\
-.470 \\
.240 \\
-.426 \\
.403 \\
.437 \\
.102 \\
.163 \\
-.268 \\
-.324\end{array}$ & $\begin{array}{c}1 \\
-.167 \\
.764^{*} \\
-.748^{*} \\
-.715^{*} \\
-.190 \\
.009 \\
.117 \\
-.112\end{array}$ & $\begin{array}{c}1 \\
-.177 \\
.162 \\
.168 \\
.182 \\
.054 \\
-.023 \\
-.027\end{array}$ & $\begin{array}{c}1 \\
-.328 \\
-.299 \\
.222 \\
.223 \\
.238 \\
.049\end{array}$ & $\begin{array}{c}1 \\
.974^{*} \\
.541^{*} \\
-.000 \\
-.133 \\
-.118\end{array}$ & $\begin{array}{c}1 \\
.513^{*} \\
.005 \\
-.101 \\
-.138\end{array}$ & $\begin{array}{c}1 \\
-.018 \\
.341 \\
.191\end{array}$ & $\begin{array}{c}1 \\
-.364 \\
-.138\end{array}$ & $\begin{array}{c}1 \\
.656^{*}\end{array}$ & 1 \\
\hline
\end{tabular}

*Correlation is significant at 0.01 level (2-tailed)

Table 5. Total variance of heavy metal content

\begin{tabular}{c|c|c|c|c|c|c}
\hline \multirow{2}{*}{ Component } & \multicolumn{4}{|c|}{ Initial eigenvalues } & \multicolumn{3}{c}{ Extraction sums of squared loadings } \\
\cline { 2 - 7 } & Total & \% of variance & Cumulative \% & Total & \% of variance & Cumulative \% \\
\hline 1 & 2.452 & 30.649 & 30.649 & 2.452 & 30.649 & 30.649 \\
2 & 1.441 & 18.007 & 48.656 & 1.441 & 18.007 & 48.656 \\
3 & 1.305 & 16.311 & 64.967 & 1.305 & 16.311 & 64.967 \\
4 & 1.159 & 14.493 & 79.460 & 1.159 & 14.493 & $\mathbf{7 9 . 4 6 0}$ \\
5 & .763 & 9.540 & 89.000 & & & \\
6 & .474 & 5.920 & 94.920 & & & \\
7 & .365 & 4.568 & 99.488 & & & \\
8 & .041 & .512 & 100.000 & & & \\
\hline
\end{tabular}

Extraction method: principal component analysis

Table 6. Component matrix ${ }^{a}$; extraction method: principal component analysis

\begin{tabular}{c|c|c|c|c}
\hline & \multicolumn{5}{|c}{ Component } \\
\cline { 2 - 5 } & $\mathbf{1}$ & $\mathbf{2}$ & $\mathbf{3}$ & $\mathbf{4}$ \\
\hline $\mathrm{Pb}$ & $\mathbf{. 6 0 0}$ & .483 & -.317 & -.316 \\
$\mathrm{As}$ & -.073 & .379 & $\mathbf{. 7 0 6}$ & .469 \\
$\mathrm{Cu}$ & .217 & $\mathbf{. 7 8 8}$ & -.089 & -.254 \\
$\mathrm{Fe}$ & .310 & .414 & -.170 & .734 \\
$\mathrm{Mn}$ & $\mathbf{. 8 0 0}$ & -.304 & .421 & .023 \\
$\mathrm{Al}$ & $\mathbf{. 8 8 0}$ & -.246 & .268 & -.150 \\
$\mathrm{Ni}$ & $\mathbf{. 6 9 8}$ & -.046 & -.191 & .103 \\
$\mathrm{Sr}$ & .204 & -.341 & -.619 & .450 \\
\hline
\end{tabular}

a 4 components extracted 


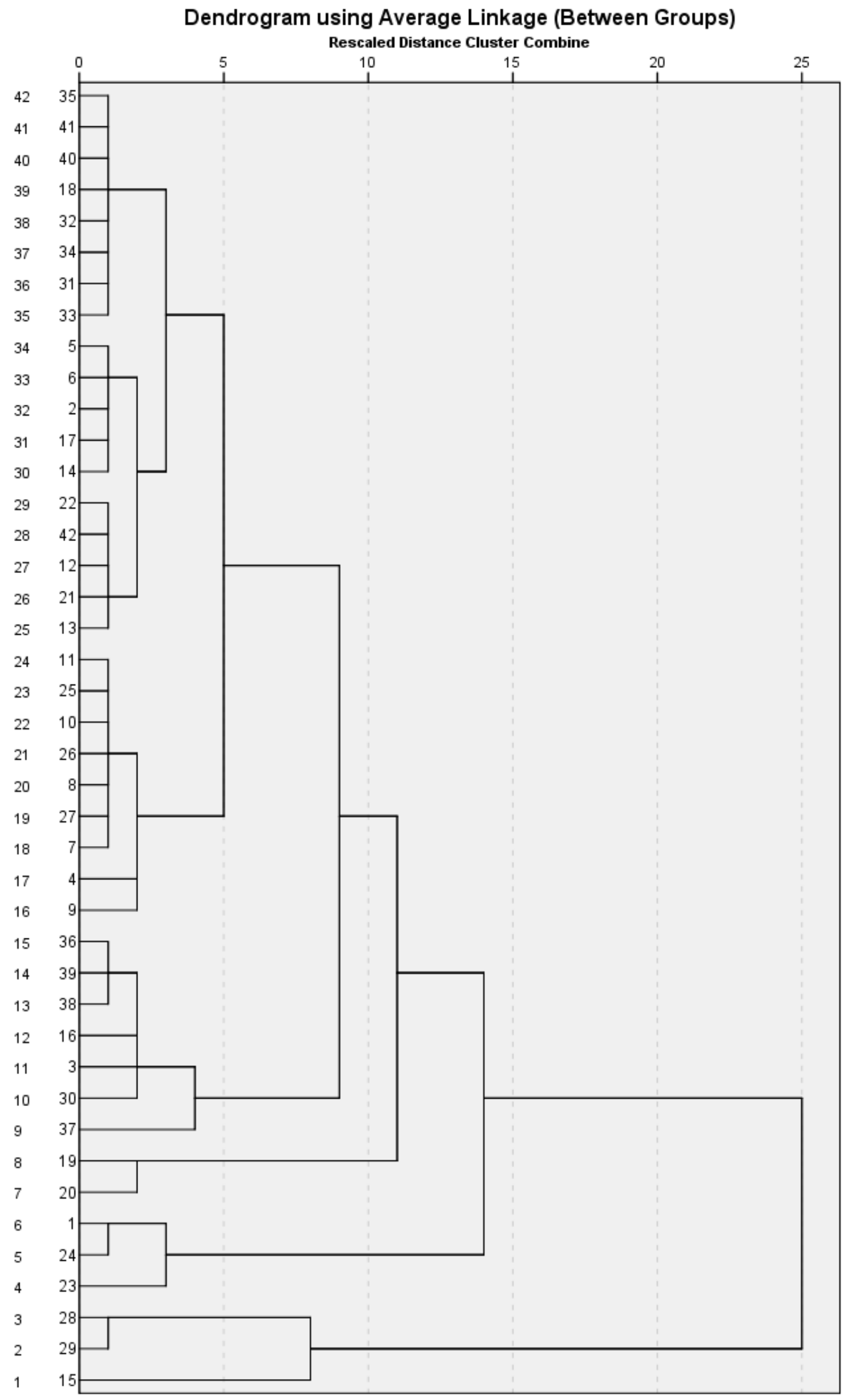

Figure 2. Dendrogram of the results

APPLIED ECOLOGY AND ENVIRONMENTAL RESEARCH 17(2):2423-2436.

http://www.aloki.hu • ISSN 15891623 (Print) • ISSN 17850037 (Online)

DOI: http://dx.doi.org/10.15666/aeer/1702_24232436

(c) 2019, ALÖKI Kft., Budapest, Hungary 


\section{Heavy metal pollution index (HPI)}

The pollution indexes are used to estimate the pollution of the water. Generally, heavy metal pollution index (HPI), heavy metal evaluation index (HEI) and degree of contamination $(C d)$ are used to evaluate water for drinking as well as irrigation purposes (Brraich and Jangu, 2015). Mehrabi et al. (2015) have also used heavy metal pollution index (HPI) to evaluate the level of contamination both in groundwater and in soil in Ahangaran mining area, Iran. They reported that HPI values were less than the critical index limit. Bhuiyan et al. (2015) have studied in Buriganga River, Bangladesh. The results showed that most of the samples exceeded the critical limit and "the intensity of pollution gradually decreased from the source to the downstream part of the river". Yang et al. (2015) have studied during the period 2008-2012 to understand the contamination in terms of heavy metal pollution and also used HPI for that. They had the following result: "The general trend of reduction in HPI appears not to have a seasonal variation and most likely resulted from the continued improvement in heavy metal pollution control strategies implemented by local environmental, agencies combined with a significant improvement in wastewater treatment capacities."

Prasad and Bose (2001) proposed the heavy metal pollution index (HPI) (Nasrabadi, 2015). The analysis results were interpreted based on these papers, in this study. Based on the weighted arithmetic average method, HPI shows the total quality of water compared to heavy metals (Horton, 1965; Mohan et al., 1996). The Heavy Metal Pollution Index (HPI) and the sub-index of each parameter (Qi) are calculated using the following correlations (Eq. 1$)$.

$$
Q_{i}=\sum_{i=1}^{n} \frac{\left(M_{i}-I_{i}\right)}{\left(S_{i}-I_{i}\right)} \times 100 \quad H P I=\frac{\sum_{i=1}^{n} W_{i} Q_{i}}{\sum_{i=1}^{n} W_{i}}
$$

Wi is the unit weight of the $\mathrm{i}$-th parameter, and Qi is the sub-index of the $\mathrm{i}$-th parameter. $\mathrm{n}$ is the number of parameters considered. $\mathrm{Mi}$ is the measured value of the parameter $\mathrm{i}$. Ii and Si give the ideal and standard values of the i-th parameter. The HPI calculations are shown in Table 7. The average of HPI is 80.38833 for Duden Stream, 60.13997 for Goksu Stream. The graphical representations of the results are presented in Table 8 with heavy metal pollution index (HPI) values. All values, except values of D15 - D19 - D20 - G13 samples, are below the 100 .

Figure 3 shows the distribution of the heavy metal pollution index (HPI) values at the stations in the study area. The critical pollution index value is 100; this and above this value should be considered unacceptable (Prasad and Kumari, 2008; Prasad and Mondal, 2008; Reza and Singh, 2010; Ojekunle et al., 2016). According to Sirajudeen et al. (2014) the status categories of HPI are given in Table 9. According to the table there is no water in "very good" category. 14 water samples have been classified as "good" (D1 - D2 - D11 - D14 - D21 - G1 - G3 - G7 - G8 - G11 - G12 - G14 - G15 - G17); 20 water samples as "poor" (D3 - D4 - D5 - D7 - D8 - D10 - D12 - D13 - D16 - D18 - D22 - D23 - G2 - G4 - G5 - G6 - G9 - G10 - G16 - G18) and 8 water samples as "very poor (unsuitable for drinking)" (D6 - D9 - D15 - D17 - D19 - D20 - D24 - G13). The HPI values of D15 - D19 - D20 and G13 samples were well above the limit.

The high HPI values were due to industrial waste waters, domestic sewage and landfill leachate (Milivojevic et al., 2016). 
Table 7. HPI calculations for both of the streams

\begin{tabular}{c|c|c|c|c|c|c|c|c|c}
\hline \multicolumn{3}{c|}{} & \multicolumn{3}{c|}{ DUDEN n = 24 } & \multicolumn{3}{c}{ GOKSU n = 18 } \\
\hline $\begin{array}{c}\text { Heavy } \\
\text { metals }\end{array}$ & $S_{i}$ & $I_{i}$ & $W_{i}$ & $M_{i}$ & $Q_{\mathrm{i}}$ & $W_{\mathrm{i}} \mathrm{x} Q_{\mathrm{i}}$ & $M_{\mathrm{i}}$ & $Q_{\mathrm{i}}$ & $W_{\mathrm{i}} \mathrm{x} Q_{\mathrm{i}}$ \\
\hline $\mathrm{As}$ & 50 & 10 & 0.02 & 9.95 & -0.125 & -0.0025 & 6.8666 & -7.8335 & -0.15667 \\
$\mathrm{Cr}$ & 10 & - & 0.1 & 0.2083 & 2.083 & 0.2083 & 0.8 & 8 & 0.8 \\
$\mathrm{Mn}$ & 300 & 100 & 0.003333 & 17.8916 & -41.0542 & -0.13685 & 2.4944 & -48.7528 & -0.16251 \\
$\mathrm{Fe}$ & 1000 & 100 & 0.001 & 197.2083 & 10.80092 & 0.010801 & 193.6111 & 10.40123 & 0.010401 \\
$\mathrm{Ni}$ & 20 & - & 0.05 & 8.3945 & 41.9725 & 2.098625 & 7.2055 & 36.0275 & 1.801375 \\
$\mathrm{Cu}$ & 1000 & 50 & 0.001 & 8.3041 & -4.38904 & -0.00439 & 4.6944 & -4.76901 & -0.00477 \\
$\mathrm{Se}$ & 10 & - & 0.1 & 0.2083 & 2.083 & 0.2083 & 0.0666 & 0.666 & 0.0666 \\
$\mathrm{Al}$ & 10 & - & 0.1 & 18.1 & 181 & 18.1 & 7.4166 & 74.166 & 7.4166 \\
$\mathrm{~Pb}$ & 50 & - & 0.02 & 1.7666 & 3.5332 & 0.070664 & 1.1777 & 2.3554 & 0.047108 \\
$\mathrm{Sr}$ & 50 & - & 0.02 & 320.875 & 641.75 & 12.835 & 379 & 758 & 15.16 \\
\hline \multicolumn{3}{c|}{ Total } & 0.415333 & \multicolumn{3}{c|}{ Total } & 33.38795 & \multicolumn{3}{c}{ Total } & 24.97814 \\
\hline
\end{tabular}

Table 8. The values of heavy metal pollution index (HPI)

\begin{tabular}{|c|c|c|c|}
\hline \multicolumn{2}{|c|}{ DUDEN } & \multicolumn{2}{|c|}{ GOKSU } \\
\hline Station & HPI & Station & HPI \\
\hline D1 & 43.99435 & G1 & 47.56614 \\
\hline D2 & 46.92572 & $\mathrm{G} 2$ & 51.28629 \\
\hline D3 & 72.53699 & G3 & 49.65717 \\
\hline D4 & 66.4472 & G4 & 70.34977 \\
\hline D5 & 60.97661 & G5 & 66.32724 \\
\hline D6 & 78.40037 & G6 & 51.17769 \\
\hline D7 & 57.75208 & G7 & 46.7238 \\
\hline D8 & 55.7768 & G8 & 43.55147 \\
\hline D9 & 98.8178 & G9 & 65.68706 \\
\hline D10 & 59.78249 & G10 & 63.56285 \\
\hline D11 & 47.09795 & G11 & 42.73846 \\
\hline D12 & 52.10245 & G12 & 43.20092 \\
\hline D13 & 53.28856 & G13 & 176.502 \\
\hline D14 & 40.82054 & G14 & 41.40662 \\
\hline D15 & $\mathbf{1 7 7 . 8 9 1 7}$ & G15 & 47.44171 \\
\hline D16 & 67.32998 & G16 & 73.99047 \\
\hline D17 & 93.24475 & G17 & 38.35314 \\
\hline D18 & 51.15154 & G18 & 71.67112 \\
\hline D19 & 242.1338 & & \\
\hline D20 & 232.0681 & & \\
\hline D21 & 47.98676 & & \\
\hline D22 & 70.51553 & & \\
\hline D23 & 62.16189 & & \\
\hline D24 & 80.9329 & & \\
\hline
\end{tabular}




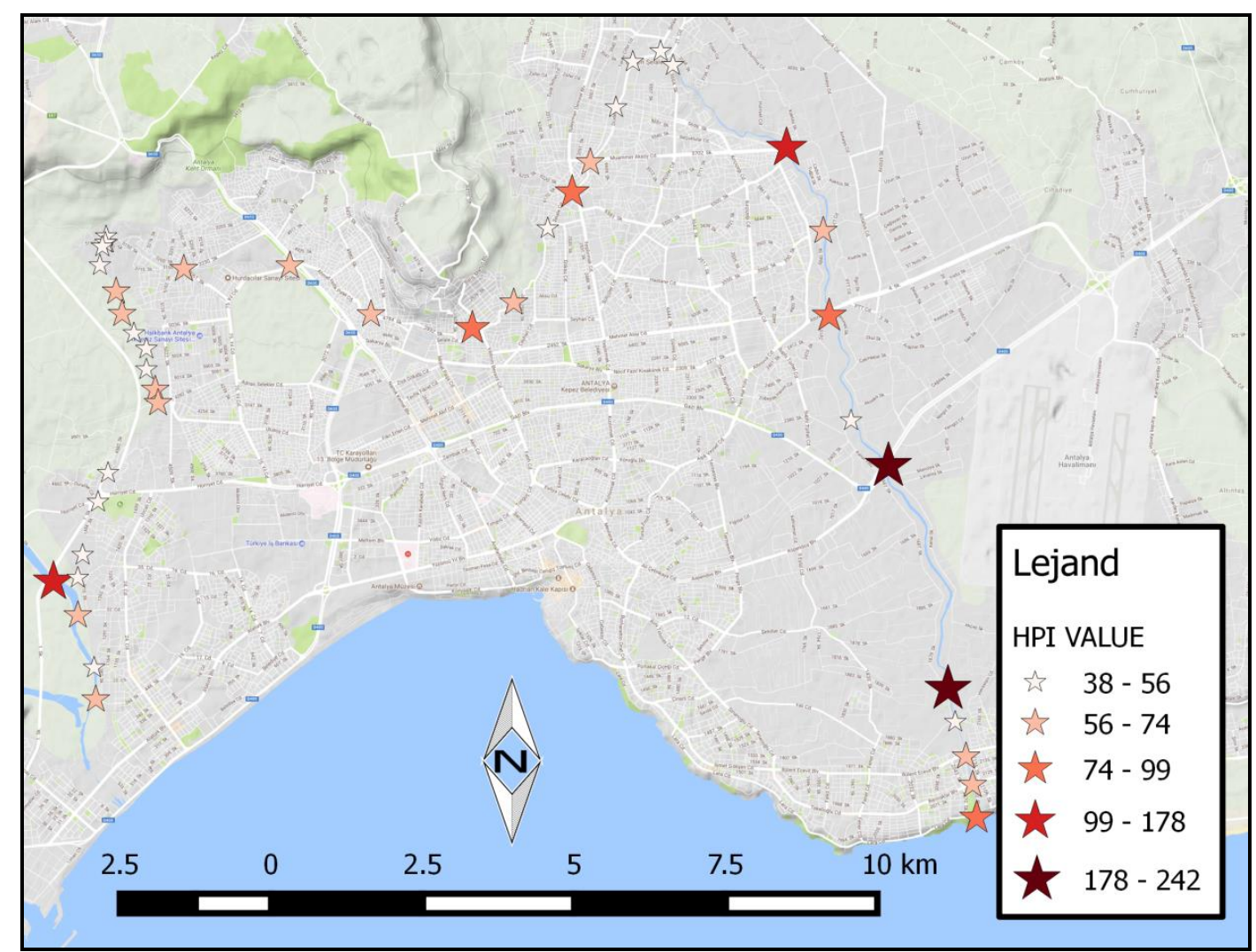

Figure 3. The distribution of the heavy metal pollution index (HPI) values at the stations in the study area

Table 9. Status categories of HPI

\begin{tabular}{c|c|c}
\hline HPI & $\begin{array}{c}\text { Quality of water } \\
\text { (Sirajudeen et al., 2014) }\end{array}$ & Stations of study area (Duden and Goksu Streams) \\
\hline $0-25$ & Very good & --- \\
\hline $26-50$ & Good & D1, D2, D11, D14, D21, G1, G3, G7, G8, G11, G12, G14, \\
G15, G17
\end{tabular}

\section{Conclusions}

The metal pollution ratio between the Kepez Hydroelectric Power Plant and the Karpuzkaldiran waterfall, which is defined as the "Lower Duden of the Duden Stream" in Lara and also surface water between Kepez Hydroelectric Power Plant and Bogacay River in Konyaaltı district, named Goksu Stream, were investigated using the HPI method. Firstly, aluminum ( $\mathrm{Al})$, lead $(\mathrm{Pb})$, arsenic $(\mathrm{As})$, copper $(\mathrm{Cu})$, manganese $(\mathrm{Mn})$, iron $(\mathrm{Fe})$, nickel $(\mathrm{Ni})$, cobalt $(\mathrm{Co})$, strontium $(\mathrm{Sr})$, chromium $(\mathrm{Cr})$, selenium $(\mathrm{Se})$, antimony $(\mathrm{Sb})$, mercury $(\mathrm{Hg})$ and cadmium $(\mathrm{Cd})$ elements were investigated. Antimony $(\mathrm{Sb})$, cadmium $(\mathrm{Cd})$ and mercury $(\mathrm{Hg})$ were undetectable and cobalt $(\mathrm{Co})$ remained below the reporting limit. 
The mean values of aluminum $(\mathrm{Al})$ and strontium $(\mathrm{Sr})$ concentrations exceeded the permitted standard values, while the concentration of other metals remained well below the permissible standard, according to the descriptive statistics of the metal concentration of Duden Stream. When the relations between 10 heavy metal behaviours in stream water in 24 different stations were examined by multivariate analyses; the correlation between $\mathrm{Cu}$ and $\mathrm{Pb}, \mathrm{Fe}$ and $\mathrm{Pb}, \mathrm{Ni}$ and $\mathrm{Pb}, \mathrm{As}$ and $\mathrm{Cr}$, As and $\mathrm{Se}, \mathrm{Mn}$ and metals were positively correlated, respectively, $\mathrm{Cr}$ and $\mathrm{Sr}$ have the same values and are highly correlated. The HPI critical value is set at 100 according to the literature. Accordingly, it has been determined that the calculated HPI value in water samples D15, D19 and D20 is well above the predicted critical value. The HPI value was consistent with multivariate statistical analyses.

4 factors influenced to the streams at high level with $79.460 \%$. This value shows that the data used in the statistical analyzes are sufficient to explain the factors. The cumulative value calculated by SPSS shows that the percentage of explanations is high and adequate for 4 different factors.

The chemical similarities between the sampling stations show that there are 3 different locations in the region. According to the hierarchical analysis; 28, 29 and 15 samples have formed their dendrogram among themselves; 1, 24 and 23 samples have formed their dendrogram among themselves and all remaining samples have formed their dendrogram among themselves. The main reason of this grouping is the natural and anthropogenic effects.

The Goksu samples, according to the descriptive statistics of the metal concentration of the surface water, only the mean values of the concentration of strontium ( $\mathrm{Sr}$ ) exceeded the allowable standard values, while the concentration of other metals was far below the permissible standard. When the relationship between 10 heavy metal behaviours in stream water at 18 different stations was examined, it was found that there was a positive correlation between As and Fe, As and $\mathrm{Mn}$, As and $\mathrm{Al}, \mathrm{Mn}$ and $\mathrm{Al}, \mathrm{Mn}$ and $\mathrm{Ni}, \mathrm{Al}$ and $\mathrm{Ni}, \mathrm{Cr}$ and $\mathrm{Se}$ metals respectively. It has been determined that the calculated HPI value in the case of water number G13 is above the predicted critical value.

There is no water in "very good" category. 14 water samples have been classified as "good" 20 water samples as "poor" and 8 water samples as "very poor (unsuitable for drinking)". The HPI values of D15, D19, D20 and G13 samples were well above the limit. So, it is understood that the main source of pollution is anthropogenic.

Acknowledgements. The financial support of the Scientific Research Projects Unit of Akdeniz University is gratefully acknowledged.

\section{REFERENCES}

[1] ASTM (1985): Standard specification for reagent water. Annual Book of ASTM Standards 11(01): D1193-77.

[2] Bhuiyan, M. A., Dampare, S. B., Islam, M. A., Shigeyuki, S. (2015): Source apportionment and pollution evaluation of heavy metals in water and sediments of Buriganga River, Bangladesh, using multivariate analysis and pollution evaluation indices. - Environ Monit Assess 187: 4075. 
[3] Brraich, O. S., Jangu, S. (2015): Evaluation of water quality pollution indices for heavy metal contamination monitoring in the water of Harike Wetland (Ramsar Site), India. International Journal of Scientific and Research Publications 5(2): 2250-3153.

[4] Cengiz, M. F., Kilic, S., Yalcin, F., Kilic, M., Yalcin, M. G. (2017): Evaluation of heavy metal risk potential in Bogacayi River water (Antalya, Turkey). - Environmental Monitoring and Assessment 189(6): 248.

[5] Demarco, C. F., Afonso, T. F., Pieniz, S., Quadro, M. S., Camargo, F. A., Andreazza, R. (2018): In situ phytoremediation characterization of heavy metals promoted by Hydrocotyle ranunculoides at Santa Bárbara stream, an anthropogenic polluted site in southern of Brazil. - Environmental Science and Pollution Research 25(28): 2831228321.

[6] EPA 3005A (1992): Acid Digestion of Waters for Total Recoverable or Dissolved Metals for Analysis by FLAA or ICP Spectroscopy. - EPA, Washington, DC.

[7] Erdem, A., Topkaya, B. (2004): Determination of land pollutants carried into the Mediterranean coastal zone by the Duden River, Antalya. - Fresenius Environmental Bulletin 13(11B): 1339-1343.

[8] Horton, R. K. (1965): An index system for rating water quality. - J Water Pollut Control Federation 3: 300.

[9] Leventeli, Y., Yalcin, F., Kilic, M. (2017): Statistical investigation of heavy metal pollution between Kepez HPP and Bogacay (Antalya-Turkey). - World Multidisciplinary Earth Sciences Symposium 11-15.09.2017, Prague, Czech Republic.

[10] Mehrabi, B., Mehrabani, S., Rafiei, B., Yaghoubi, B. (2015): Assessment of metal contamination in groundwater and soils in the Ahangaran mining district, west of Iran. Environ Monit Assess 187: 727.

[11] Milivojevic, J., Krstic, D., Smit, B., Djekic, V. (2016): Assessment of heavy metal contamination and calculation of its pollution index for Ugljesnica River, Serbia. - Bull. Environ. Contam. Toxicol. 97: 732-742.

[12] Mohan, S. V., Nithila, P., Reddy, S. J. (1996): Estimation of heavy metal in drinking water and development of heavy metal pollution index. - J. Environ. Sci. Health A31(2): 283.

[13] Nasrabadi, T. (2015): An index approach to metallic pollution in river waters. - J. Environ. Res. 9(1): 385-394.

[14] Prasad, B., Bose, J. M. (2001): Evaluation of the heavy metal pollution index for surface and spring water near a limestone mining area of the lower Himalayas. - Environmental Geology 41: 183-188.

[15] Prasad, B., Kumari, S. (2008): Heavy metal pollution index of ground water of an abandoned open cast mine filled with fly ash: A case study. - Mine Water Environ. 27(4): 265-267.

[16] Prasad, B., Mondal, K. K. (2008): The impact of filling an abandoned opencast mine with fly ash on ground water quality: A case study. - Mine Water Environ. 27(1): 40-45.

[17] Reza, R., Singh, G. (2010): Heavy metal contamination and its indexing approach for river water. - Int. J. Environ. Sci. Tech. 7(4): 785-792.

[18] Rohrbough, W. G. et al. (1986): Reagent Chemicals, American Chemical Society Specifications, 7th Ed. - American Chemical Society, Washington, DC.

[19] Sirajudeen, J., Arulmanikandan, S., Manivel, V. (2014): Heavy metal pollution index of groundwater of Fathima Nagar Area near Uyyakondan Channel Tiruchirappalli District, Tamil Nadu, India. - World Journal of Pharmacy and Pharmaceutical Sciences 4(1): 967975.

[20] Sobhanardakani, S. (2016): Evaluation of the water quality pollution indices for groundwater resources of Ghahavand Plain, Hamadan Province, Western Iran. - Iranian Journal of Toxicology 10(3): 35-40.

[21] Sodrzeieski, P. A., Andrade, L. C. D., Tiecher, T., Camargo, F. A. D. O. (2018): Physicochemical variability and heavy metal pollution of surface sediment in a non-channelled 
section of Dilúvio Stream (Southern Brazil) and the influence of channelled section in sediment pollution. - Revista Ambiente \& Água 14(1).

[22] Stoica, A., Baiulescu, G. E. (2008): Global pollution. - Proceedings of Ecopole 2(1): 119121.

[23] Ojekunle, O. Z., Ojekunle, O. V., Adeyemi, A. A., Taiwo, A. G., Sangowusi, O. R., Taiwo, A. M., Adekitan, A. A. (2016): Evaluation of surface water quality indices and ecological risk assessment for heavy metals in scrap yard neighbourhood. - SpringerPlus 5: 560 .

[24] Omwene, P. I., Öncel, M. S., Çelen, M., Kobya, M. (2018): Heavy metal pollution and spatial distribution in surface sediments of Mustafakemalpaşa stream located in the world's largest borate basin (Turkey). - Chemosphere 208: 782-792.

[25] Uncumusaoglu, A. A., Sengul, U., Akkan, T. (2016): Environmental Contamination of Heavy Metals in the Yaglidere Stream (Giresun), Southeastern Black Sea. - Fresen. Environ. Bull. 25(12): 5492-5498.

[26] Yalcin, F., Kilic, S., Nyamsari, D. G., Yalcin, M. G., Kilic, M.,(2016): Principal component analysis of integrated metal concentrations of Bogacayi riverbank sediments in Turkey. - Polish Journal of Environmental Studies 25(2): 471-485.

[27] Yang, X., Duan, J., Wang, L., Li, W., Guan, J., Beecham, S., Mulcahy, D. (2015): Heavy metal pollution and health risk assessment in the Wei River in China. - Environ Monit Assess 187: 111.

[28] Yardimci, A., Muhammetoglu, A., Oguz, H. (2005): A Fuzzy Logic Application to Environment Management System: A case Study for Goksu Streams Water Quality Assessment. - In: Reusch, B. (ed.) Computational Intelligence, Theory and Applications. Advances in Soft Computing, Vol. 33. Springer, Berlin, Heidelberg, pp. 327-338.

[29] Ye, C., Butler, O. M., Du, M., Liu, W., Zhang, Q. (2019): Spatio-temporal dynamics, drivers and potential sources of heavy metal pollution in riparian soils along a 600 kilometre stream gradient in Central China. - Science of the Total Environment 651: 1935-1945.

[30] Zarazua G, Avila-Perez P, Tejeda S, Barcelo-Quintal I, Martinez, T. (2006): Analysis of total and dissolved heavy metals in surface water of a Mexican polluted river by total reflection X-ray fluorescence spectrometry. - Spectrochim Acta B 61: 1180-4. 